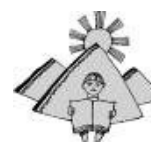

doi: 10.15330/msuc.2017.17.41-44

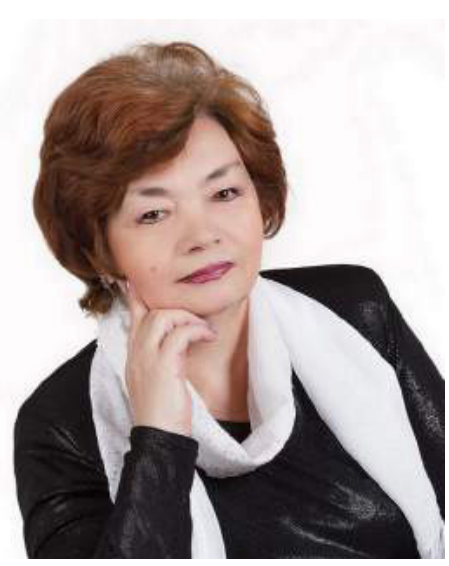

Віра Мелешко,

кандидат педагогічних наук, доцент, провідний науковий співробітник відділу економіки та управління загальною середньою освітою Інституту педагогіки НАПН України

(м. Київ)

Vira Meleshko,

Candidate of Pedagogical Sciences, Associate Professor, Leading Researcher, Department of Economics and Management of General Secondary Education Institute of Pedagogy of the National Academy of Sciences of Ukraine (Kyiv) nauk_org_undip@ukr.net

УдК 37. 013

\title{
ПРОБЛЕМИ РОЗВИТКУ ГІРСЬКОЇ ШКОЛИ ЗА УМОВ РЕФОРМУВАННЯ ШКІЛЬНОЇ ОСВІТИ
}

\section{PROBLEMS OF DEVELOPMENT OF MOUNTAIN SCHOOL IN THE CONDITIONS OF IMPLEMENTATION OF REFORM OF SCHOOL EDUCATION}

Стаття присвячена проблемам функціонування гірських шкіл у сучасних умовах, окреслює перспективи розвитку тих інституцій, які потребують особливої уваги держави та суспільства.

Ключові слова: гірська школа, розвиток гірської школи, умови роботи гірської школи, особливості роботи вчителя гірської школи.

The article is devoted to the problems of functioning of mountain schools in modern conditions, outlines the prospects for the development of such institutions, which require special attention of the state and society.

Keywords: Mountain school, development of mountain school, working conditions of the mountain school, peculiarities of the work of the mountain school teacher,

Статья посвящена проблемам функционирования горных школ в современных условиях, определяет перспективы развития тех институтов, которые требуют особого внимания государства и общества.

Ключевые слова: горная школа, развитие горной школы, условия работы горной школы, особенности работы учителя горной школы.

Сьогодні освіта України вийшла за межі освітянської проблеми, до вирішення яких залучені найширші кола суспільства, що зацікавлене в її розвитку. В умовах децентралізації управління необхідно зосередити увагу на тих регіональних особливостях, які є визначальними як для соціальної сфери, так і сфери освіти.

Окремим модулем в системі освіти виступає сільська школа, в освітньому просторі нашої країни вона займає 70\% від загальної кількості загальноосвітніх навчальних закладів, (що нараховують 11,571 од., в яких навчається1 183662 учнів) [2].

Серед загальної кількості освітніх закладів є такі, що функціонують в особливих умовах. Це гірські школи, які розташовані на території 27 районів 4 областей України: Закарпатської, Львівської, Чернівецької та ІваноФранківської, тобто, наділені статусом гірських. У них функціонують приблизно 600 загальноосвітніх навчальних закладів, в яких навчається близько 120 тис учнів.

Зокрема тільки в Івано-Франківській області третина загальноосвітніх навчальних закладів (близько 200) розташовані в гірській місцевості.

У гірській місцевості цих областей функціонує 7 гімназій, 3 ліцеї та 209 дошкільних навчальних закладів.

Загалом у сільській школі, в тому числі й гірській, спостерігається зниження співвідношення учнів/учитель, (13,3 - 1990 році, 8,5 в 2015, ), в окремих малих школах - 5 уч., що породжує зростання малокомплектності, а відтак і здорожчання витрат на фінансування навчання одного учня.

у 2015 році навчання учня було найдорожчим у двох областях із низьким рівнем урбанізації та наявністю гірських шкіл: в Івано-Франківській і Закарпатській областях: 15.1 та 12.1 тис грн на учня відповідно.

Гірська школа - це поліфункціональний заклад, що здійснює педагогічну та соціальну функцію, реалізує комплекс освітніх завдань, які визначені Конституцією України, законами України «Про освіту», іншими 
нормативно-правовими документами. Вона зберігає генетичний потенціал українського етносу, відіграє роль науково-просвітницького, соціально-культурного та ідейно-духовного середовища територіальної громади.

Як зазначається в новому Законі Україні «Про освіту» (Розділ1, стаття 3 ), «В Україні створюються рівні умови доступу до освіти. Ніхто не може бути обмежений у праві на здобуття освіти. Право на освіту гарантується незалежно від віку, статі, раси, стану здоров'я, інвалідності, громадянства, національності, політичних, релігійних чи інших переконань, кольору шкіри, місця проживання, мови спілкування, походження, соціального і майнового стану, наявності судимості, а також інших обставин та ознак. [1]

Це означає, що діти в гірській місцевості мають право здобувати загальну середню освіту, маючи належний доступ до неї.

Водночас сучасна гірська школа, як і інші загальноосвітні навчальні заклади, покликана забезпечувати життєздатну систему безперервного навчання й виховання, повною мірою відповідати освітнім потребам учнів і запитам місцевого соціуму, що корелюються з регіональними вимогами ринку праці.

Зазначимо, що гальмівним чинником у розвитку освітніх закладів гірської місцевості, як і багатьох інших сільських шкіл, $€$ економічна слабкість регіонів, застаріла матеріально-технічна база, демографічні чинники, недостатнє кадрове забезпечення, віддаленість від культурних центрів та інше, що знижує якість соціокультурного середовища, звужує комунікаційні зв'язки; і все це негативно позначається на результатах та якості освіти учнів зазначених закладів.

Іншою проблемою для гірської місцевості $€$ нерозвиненість дорожньо-транспортної інфраструктури, віддаленість населених пунктів один від одного, що посилює складність функціонування гірської школи, ускладнює умови проживання тисячі дітей, батьків, учителів. Негативні умови спричинені також і суворим та нестабільним кліматом, низькими температурними показниками, своєрідними ландшафтно-природними умовами, що значною мірою формують специфіку гірської школи.

3 іншого боку, низький рівень фінансового забезпечення, недостатня заробітна плата, звужена чи нерозвинена інфраструктура, низький рівень життя місцевого соціуму, місцевих селян та складні умови життя не приваблюють молодих кваліфікованих кадрів до роботи у гірській школі. А це означає, що без позитивної мотивації, належного заохочення молодь не буде зацікавлена працювати в таких школах. А відтак стрімкі зміни в освітній політиці значно підвищують вимоги до вчителя, в тому числі і в гірській школі, що актуалізує проблему спеціальної підготовки вчителя до роботи в гірській місцевості.

у гірських загальноосвітніх навчальних закладах учитель має добре володіти сучасними технологіями навчання, що пов'язані з особливостями освітнього процесу у малочисельних учнівських колективах, 3 варіативністю форм та методик дистанційного та екстернатного навчання, т'юторськими технологіями та ін. Слід звернути увагу й на те, що в таких закладах навантаження вчителя формується із годин кількох предметів, що потребує відповідної фахової підготовки. Ці та інші аспекти освітнього процесу формують специфіку умов діяльності гірської школи, для якої необхідно готувати вчителя з правом викладання кількох споріднених предметів, озброєних знаннями та компетентностями, пов'язаних зі специфікою освітнього процесу.

Для успішного кадрового забезпечення населених гірських сіл необхідно розробити та реалізувати міжвідомчі програми, спрямовані на повернення до гірського села випускників вищих навчальних закладів і фахівців соціальної сфери, яких потребує місцеве населення (лікарів, учителів, працівників культури), шляхом надання першого робочого місця, можливості отримати житло тощо.

За висновками В. Д. Хруща, з гірських сіл вимиваються талановиті, освічені, тому що в селах часто немає праці та умов для застосування їх таланту, освіти, професійної підготовки [2, с. 79 ].

А це означає, що вчитель працює в специфічних умовах, що зобов'язує враховувати середовище формування дитини, її близькість спілкування з природою, що впливає на подальше становлення та розвиток особистості. Адже дитина, сформована у гірській місцевості, характеризується підвищеною активністю, винахідливістю, працьовитістю, швидкою адаптивністю до змін.

За спостереженнями педагогів вищих навчальних закладів, випускники з віддалених сіл під час навчання у вузі відстають за показниками навчання лише впродовж перших двох років, а потім значно випереджають своїх однокурсників. Все це свідчить про те, що без урахування особливостей функціонування гірської школи неможливо домогтися високої якості освіти, яка б відповідала потребам місцевого соціуму та сучасним викликам, що робить такі заклади специфічними і особливими в динамічному геопросторі.

В умовах децентралізації управління відбувається оптимізація та модернізація освітньої мережі, здійснюється перегляд доцільності функціонування окремих шкіл, особливо малокомплектних, що часто активізує та підвищує тривожність у суспільстві. Органи місцевого самоврядування у цих умовах мають добре володіти інформацією щодо стану освітньої мережі на території громади або району та всебічно сприяти збереженню та розвитку існуючих закладів, особливо тих, що в своєму складі мають початкову ланку чи здійснюють дошкільну підготовку дітей чи реалізують програми профільного навчання.

Питання, пов'язані із оновленням освітньої мережі, мають всебічно вивчатися, супроводжуватися чіткою і зрозумілою аргументацією дій, обґрунтованими причинами для запобігання негативних чинників та уникнення можливих ризиків, що можуть виникати після ліквідації закладу. 3 особливою обережністю треба ставитися до 
школи у малих віддалених, фізично ізольованих селах депресивних районів, де транспортування учнів і вчителів до школи процес практично неможливий.

Для стабільної діяльності гірських шкіл необхідно унормувати окремі документи з урахуванням їх особливостей, зокрема переглянути кількісні показники наповнюваності класів, шкіл, опорних шкіл, умов створення освітніх округів, адже вони не можуть бути такими, як встановлено для традиційних освітніх закладів. Наприклад, освітній округ може функціонувати за наявності однієї школи, і не обов'язково у його складі має бути школа - філія. Також вважаємо, що в громаді може бути кілька опорних шкіл за напрямами, профілями чи проблемами.

Заслуговують максимального збереження школи I-III ст. Слід подбати, щоб у гірській місцевості старшокласники повну загальну середньою освіту могли здобувати за місцем проживання, а для цього потрібно відновити інтернатні заклади. Слід створювати умови для ширшого використання таких форм навчання, як індивідуальні, очно-заочні, інформальні, дуальні, дистанційні, екстернатні та ін.

Відповідно до вимог ринкової економіки, освітній процес у старшій школі має бути наближений до потреб та інтересів учнів і пов'язаний з їх майбутньою професією. А це означає, що випускник має бути озброєний відповідними знаннями, володіти набором сформованих компетентностей, що забезпечать йому можливість бути успішним, конкурентоздатним, конкурентоспроможним в сучасному мінливому житті. Для усвідомленого вибору майбутньої професії, подальшого самовизначення старшокласникам необхідно надати ширший спектр вибору спеціальних груп, класів, профільних курсів, факультативів, що створюються на базі опорних шкіл. Розвиток профільної освіти стане передумовою для подальшого розвитку в гірській місцевості підприємницької активності у традиційних сферах господарства: розвитку туризму, лісового господарства, сервісних послуг, тваринництва, прикладного мистецтва, інших народних промислів, які забезпечуватимуть розвиток гірських районів.

Все це сьогодні вимагає додаткових коштів; крім державних інвестицій, можливо, це будуть новостворені спеціальні фонди, благодійні структури чи інші проекти.

Тобто для освітніх закладів гірської місцевості мають бути узаконені певні преференції, винятки, оскільки умови навчання в цих районах значно складніші, ніж у школах низинних районів. Гірські школи мають отримати відповідний статус, а учні в повному обсязі повинні скористатися ним.

Ми схвально ставимося до пропозицій, які виносилися на засідання Комітету Верховної Ради України щодо доповнень до проекту Закону України «Про внесення змін до деяких законів України щодо посилення державних гарантій для гірських та високогірських населених пунктів» (реєстр. № 6439). Державної підтримки потребують питання, що пов'язані із збільшенням тарифних ставок, пенсійного забезпечення для працівників медичних, освітніх закладів, закладів культури та інших бюджетних установ, які розташовані на території високогірних населених пунктів.

У рішенні Комітету Верховної Ради рекомендовано Кабінету Міністрів України розробити Концепцію сільської загальноосвітньої школи, в якій визначити місію та роль гірської школи як важливої ланки регіональної освіти, як осередку збереження своєрідних традицій, що розвиваються в нових умовах, які покликані збалансувати природно-етнічні, інноваційні впливи засобами інформаційних технологій.

Також передбачено вивчення доцільності впровадження пільгового оподаткування для новостворених підприємницьких структур на території гірських районів, які у процесі виробничої діяльності надаватимуть допомогу у розвитку соціально-освітніх послуг або здійснення інфраструктурного забезпечення цих територій, що значно покращить умови діяльності загальноосвітніх навчальних закладів.

Одним із пунктів Постанови передбачено розроблення довгострокової програми розвитку гірських територій, яка визначить їх статус як об'єкта регулювання, створить правові засади для їх розвитку, забезпечить формування освітнього середовища для школярів зазначених територій.

Рекомендовано областям, райони яких розташовані на гірських територіях, вивчити питання щодо доцільності створення на рівні областей, у яких функціонують гірські школи, спеціального освітянського телевізійного каналу, який спільно з Інтернет-мережею дозволяв би ефективно обмінюватися інформацією та досвідом використання сучасних технологій, у тому числі й дистанційного навчання в гірських школах. Такі заходи сприятимуть вести різноманітні навчально-пізнавальні програми, телепередачі тощо.

Міністерству освіти і науки України рекомендовано забезпечити безумовне фінансування в повному обсязі варіативного компонента навчального плану, ширше використовувати його для поглиблення знань учнів про рідний край, соціально-економічні особливості життя і господарювання в горах, на підготовку до вибору майбутньої професії (а почасти і її здобуття) в системі профільного навчання.

Сьогодні потребують уваги ті заклади, які раніше були закриті з тих чи інших причин. Можливо, цей процес буде втілений в перспективі, проте відновлення діяльності раніше закритих закладів освітньо-культурного призначення має бути уже реалізованим, що потребує відповідного фінансування.

За відсутності достатнього фінансування гірська школа може втратити свою специфічність, особливість, що частіше закладено в змісті предметів варіативного компоненту навчального плану. Неповне фінансування варіативного компоненту також унеможливить виконання навчальних програм, окремих предметів профільного 
навчання, що реалізується через програми курсів за вибором, спеціальні курси, що відображають специфіку гірського краю, життя горян, особливості ведення господарства, а відтак впливають на професійний вибір старшокласників.

Потребує підтримки у гірській місцевості проект щодо створення спеціального освітянського телевізійного каналу для послуг учителів.

Першочергового вирішення потребують питання оновлення матеріально-технічної бази гірських шкіл, навчальних кабінетів, шкільних майстерень, які мають велике значення в засвоєнні знань, набутті необхідних компетентностей учнями. Це буде сприяти розвитку навичок, притаманних для традиційних народних промислів, що характерні для гірської місцевості. Досить часто оволодіння технікою обробки дерева, різьби та виготовлення виробів мистецько-прикладного характеру стають для багатьох випускників професійним вибором.

Сьогодні державної підтримки потребують як гірські школи, так і багато інших сільських шкіл. 3 цією метою у змісті Концепції сільської школи слід чітко прописати основні завдання та етапи реалізації на найближчий період, надаючи преференції гірській школі, враховуючи її місію та роль як важливої ланки регіональної освіти, як осередку збереження своєрідних традицій, визначити основні вектори її розвитку, збалансувати потреби, можливості та умови функціонування, залучивши до її реалізації найширші кола зацікавлених сторін.

Для успішної реалізації основних положень Концепції підтримуємо пропозицію щодо створення Всеукраїнського фонду розвитку гірських територій, що дасть можливість акумулювати кошти для цільового використання в сфері освіти і для стимулювання молодих педагогічних кадрів.

На виконання завдань Концепції можуть бути розроблені регіональні стратегії чи програми розвитку гірських районів, де були б зазначені конкретні дії щодо розвитку освітніх та культурних закладів, що функціонують на даній території чи створення нових, зокрема природничо-наукових та шкіл з поглибленим вивченням іноземних мов; загальноосвітніх навчально-оздоровчих закладів, розвивально-мистецьких; оздоровчо-спортивних та інших.

Гірські школи не можуть сьогодні залишитися без опіки та підтримки більш потужних інституцій. Надати посильну допомогу гірським школам покликані вищі навчальні заклади, заклади системи професійно-технічної освіти, місцеві виробничі організації та структури, які зацікавлені в підготовці випускників як майбутніх спеціалістів відповідної галузі. Взаємна співпраця будується на засадах партнерства, що засвідчили свою перспективність ідеї мережевої взаємодії. Сьогодні вони втілюються в експериментальних моделях, апробація яких здійснювалася в 4 районах Івано-Франківської області, в тому числі в Манявському НВК, що належить до гірських. За результатами дослідження моделей мережевої організації профільного навчання проведено 2 конференції, 3 міжрегіональні семінари, 3 круглих столи. Наприкінці поточного року заплановано проведення підсумкової Всеукраїнської конференції за підсумками проведеного дослідження.

Зазначені вище заходи були проведені за активної участі Івано-Франківського ОІпПо та за підтримки департаменту з освіти, науки Івано-Франківської ОДА, районних управлінських структур, що сприяло поширенню наукових здобутків в педагогічну практику.

Розширенню та збагаченню освітнього простору гірських шкіл сприяють широкі міжнародні зв'язки, що посилюють процес інтеграції України в європейській простір.

Отже, лише у тісній співпраці всіх зацікавлених сторін: педагогів, науковців, владних структур, громадськості можна забезпечити поступ у розвитку національної освіти, в тому числі прискорити розвиток освіти в гірських регіонах України.

1. Закон України «Про освіту», Електронній ресурс http://zakon3.rada.gov.ua/laws/show/2145-19

2. Статистичні дані МОН України. Електронний ресурс сайту МOH (http://mon.gov.ua/usi-novivni/novini/2016/01/13/ zagalnoosvitni-navchalni-zakladi-statistika-za-dva-navchalni-roki/

3. Хрущ В Д. Розвиток освіти в Карпатському регіоні - запорука його академічної безпеки та сталого розвитку. / Гірська школа Українських Карпат. - Наукове фахове видання з педагогічних наук. - 2007. - №. 2-3. - 262 с.

\section{Reference}

1. Zakon Ukrayiny «Pro osvitu», Elektronniy resurs http://zakon3.rada.gov.ua/laws/show/2145-19

2. Statystychni dani MON Ukrayiny. Elektronnyy resurs saytu MON (http://mon.gov.ua/usi-novivni/novini/2016/01/13/ zagalnoosvitni-navchalni-zakladi-statistika-za-dva-navchalni-roki/

3. Khrushch V D. Rozvytok osvity v Karpats'komu rehioni - zaporuka yoho akademichnoyi bezpeky ta staloho rozvytku. / Hirs'ka shkola Ukrayins'kykh Karpat. - Naukove fakhove vydannya z pedahohichnykh nauk. - 2007. - №. 2-3. - 262 s. 